Metallophysics and Advanced Technologies

Металофіз. новітні технол.

Metallofiz. Noveishie Tekhnol.

2021, vol. 43, No. 8, pp. 1065-1077

https://doi.org/10.15407/mfint.43.08.1065

Reprints available directly from the publisher (c) 2021 G. V. Kurdyumov Institute for Metal Physics, National Academy of Sciences of Ukraine Published by license under

the G. V. Kurdyumov Institute for Metal PhysicsN.A.S. of Ukraine Publishers imprint. Printed in Ukraine.

PACSnumbers: 61.05.cp, 61.72.S-, 64.75.Lm, 64.75.Nx, 81.07.Bc, 81.20.Ev, 81.40.Ef

\title{
Effect of Ga Dopants on Oxidation Behaviour of YCu Compounds
}

\author{
O. I. Nakonechna, M. V. Tymoshenko, Yu. O. Titov, and N. N. Belyavina
}

Taras Shevchenko National University of Kyiv, 60 Volodymyrska Str., UA-01033 Kyiv, Ukraine

Kinetics of isothermal $\left(500,600\right.$, and $650^{\circ} \mathrm{C}$ ) oxidation of $\mathrm{YCu}_{1-x} \mathrm{Ga}_{x}$ $(0 \leq x \leq 0.3)$ solid solution powders $(50 \mu \mathrm{m}$ of size) on the base of $\mathrm{YCu}$ compound is studied by the periodic weighment method as well as by XRD phase analysis. Features of oxidation mechanism of these intermetallic powders are revealed, including two stages of oxidation process. The initial stage of oxidation is characterized by the decomposition of the $\mathrm{YCu}_{1-x} \mathrm{Ga}_{x}$ solid solution into $\mathrm{Y}(\mathrm{Cu}, \mathrm{Ga})_{2}$ phase and individual metals with gradual formation of a stable oxide scale (containing $\mathrm{Y}_{2} \mathrm{O}_{3}$ mainly). The second stage of oxidation is characterized by oxidation of the $\mathrm{Y}(\mathrm{Cu}, \mathrm{Ga})_{2}$ phase with formation of both copper and gallium oxides. This polyphase oxide scale forms significantly retards either the diffusion of atmospheric oxygen atoms along the grain boundaries or the oxidation. In a whole, the oxidation rate of the $\mathrm{YCu}_{1-x} \mathrm{Ga}_{x}$ solid solution decreases with an increase in the gallium content, while the apparent activation energy of oxidation increases. That is, gallium dopants increase the resistance to high-temperature oxidation of the $\mathrm{YCu}$ phase under its annealing at $500-650^{\circ} \mathrm{C}$ in air.

Key words: intermetallic, activation energy, oxidation rate, weight gain method, X-ray powder diffraction.

Методами періодичного зважування та рентгенівського фазового аналізу досліджено кінетику ізотермічного $\left(500,600\right.$ та $\left.650^{\circ} \mathrm{C}\right)$ окиснення порошків твердого розчину $\mathrm{YCu}_{1-x} \mathrm{Ga}_{x}(0 \leq x \leq 0,3)$ (розміром 50 мкм) на основі сполуки ҮCu. Виявлено особливості механізму окиснення цих інтерметалідних порошків, зокрема, двостадійний характер процесу. Початкова

Corresponding author: Olesya Ivanivna Nakonechna

E-mail:les@univ.kiev.ua

Citation: O. I. Nakonechna, M. V. Tymoshenko, Yu. O. Titov, and N. N. Belyavina, Effect of Ga Dopants on Oxidation Behaviour of YCu Compounds, Metallofiz. Noveishie Tekhnol., 43, No. 8: 1065-1077 (2021), DOI: 10.15407/mfint.43.08.1065. 
стадія окиснення характеризується розпадом твердого розчину $\mathrm{YCu}_{1-x} \mathrm{Ga}_{x}$ на фазу $\mathrm{Y}(\mathrm{Cu}, \mathrm{Ga})_{2}$ та індивідуальні метали 3 поступовим утворенням стійкої оксидної окалини (переважно містить $\mathrm{Y}_{2} \mathrm{O}_{3}$ ). Друга стадія процесу характеризується окисненням фази $\mathrm{Y}(\mathrm{Cu}, \mathrm{Ga})_{2}$ з утворенням оксидів як міді, так і галію. Така багатофазна оксидна окалина значно уповільнює дифузію атомів Оксигену вздовж меж зерен і процес окиснення загалом. Швидкість окиснення твердого розчину $\mathrm{YCu}_{1-x} \mathrm{Ga}_{x}$ зменшується зі збільшенням вмісту галію, тоді як енергія активації окиснення збільшується. Тобто домішки Галію підвищують корозійну стійкість фази $\mathrm{YCu}$ у разі її відпалу за $500-650^{\circ} \mathrm{C}$ у повітрі.

Ключові слова: інтерметалід, енергія активації, швидкість окиснення, метода періодичного зважування, рентгенівська дифракція.

(Received December 21, 2020; in final version, June 8, 2021)

\section{INTRODUCTION}

Among RE-Me equiatomic compounds with CsCl-type structure $(\mathrm{RE}=\mathrm{Y}, \mathrm{Dy}, \mathrm{Er}, \mathrm{Ho}, \mathrm{Me}=\mathrm{Cu}, \mathrm{Zn}, \mathrm{Ag})$ the $\mathrm{YCu}$ intermetallic is notable for such impressive mechanical characteristics as the yield strength (53-40 MPa), flow stress ( $\approx 300 \mathrm{MPa})$ and tensile strain $(6-11 \%)[1-5]$. However, the oxidation products formed on the working surfaces of these materials could cause a deterioration of functional characteristics of an item made of them. Besides, the method for preparation of material also plays a pivotal role in its final characteristics. So, for example, initial powders, using for synthesis of the intermetallics via powder metallurgy route, nearly always contain residual oxygen, and, therefore, the oxidation products are often formed even at processing under protective environment. For the same reason the bulk $\mathrm{YCu}$ samples compacting from the powders mechanically alloyed in a high energy planetary ball mill contain additional amount of $\mathrm{Y}_{2} \mathrm{O}_{3}$ oxide regardless on whether the synthesis is carried out in air [6] or in an argon atmosphere [7]

Previously, the oxidation resistance of both bulk copper and yttrium metals is determined by studying the thickness of an oxide scale in dependence on the annealing time (scaling factor) in air [8-11]. As far as we know, there is no data on oxidation kinetics of the pure Y powder or $\mathrm{YCu}$ powder. However, such studies seem to be quite important to control the processes at mechanical alloying since the high specific surface area of milling products facilitates oxidation processes.

It has been previously shown that the gallium dopants increase the oxidation resistance of some dental titanium alloys [12-14]. So, in this work the gallium metal is tested as an oxidation inhibitor for the $\mathrm{YCu}$ powder, since gallium atoms form extended solid solution not only with copper and yttrium metals but also with the most compounds of 
the $\mathrm{Y}-\mathrm{Cu}$ binary system [15]. The main aim of this work is to study the kinetics of isothermal $\left(500,600\right.$, and $\left.650^{\circ} \mathrm{C}\right)$ oxidation in air of the $\mathrm{Y}(\mathrm{Cu}, \mathrm{Ga})$ solid solution powders.

\section{EXPERIMENTAL PROCEDURES}

The kinetics of isothermal oxidation is studied on the powder samples of the $\mathrm{YCu}_{1-x} \mathrm{Ga}_{x}$ solid solution. The sources for the manufacture of these powder samples are the series of the bulk $\mathrm{YCu}_{1-x} \mathrm{Ga}_{x}$ alloys (up to $20 \%$ at. $\mathrm{Ga})$ obtained by arc melting of the yttrium $(99.8 \%$ wt.), the electrolytic copper (99.99\% wt.) and the gallium $(99.999 \%$ wt.) metals. Bulk ingots ( 7 in total) of the alloys prepared are rubbed with a rasp-file. Then the filings obtained in such way are sequentially sieved through sieves with different mesh sizes and finally they are tested by the method of particle size analysis: particle size is shown to be predominantly of $50 \mu \mathrm{m}$. For each composition studied $(0,2.5,5.0,7.5$ $10.0,12.5$, and $15 \%$ at. Ga) the sifted powder is placed into two alundum pots (the working and the control ones) with a diameter of $15 \mathrm{~mm}$. The initial weight of the powder in a pot is equal to $0.7-0.8 \mathrm{~g}$. The oxidation of the powder placed in a working pot is studied by the weight gain method, and the oxidized powder in a control pot is used for sampling for XRD study. Both pots filled with the powder of a certain composition are simultaneously heated in a muffle furnace in air. The weight gain of the powder placed in a working pot is measured on VLR20 analytical balance with an accuracy of $0.0001 \mathrm{~g}$. The oxidation degree $\alpha$ of the powder is determined as the ratio of the weight gain of the powder at oxidation time $(t)$ to the weight of this powder at initial time $(t=0)$. To ensure the best air penetration deep inside, the pots with the powder annealed are shaken up every time before they are placed into the furnace again.

In order to study the phase transformations at oxidation process by XRD method the test samples have been selected from the control pot after certain oxidation time. XRD data is collected with DRON-3 automatic diffractometer (radiation $\mathrm{Cu} K_{\alpha}$ ). The diffraction patterns are collected in a discrete mode under the following scanning parameters: observation ranges are $20^{\circ}-130^{\circ}$, step scan is $0.05^{\circ}$ and counting time per step is $3 \mathrm{~s}$.

The peak positions and integral intensities of the reflections observed are determined using the full profile analysis. Interpretation of the X-ray diffraction pattern obtained have been carried out using the original software package [6] elaborated by us using known algorithms [16] and containing full complex of standard Rietveld procedure (including qualitative and quantitative phase analysis using PDF data, lattice parameters refinement, crystal structure determination, etc.). 


\section{EXPERIMENTAL RESULTS AND DISCUSSION}

According to known isothermal section of phase diagram of the $\mathrm{Y}-\mathrm{Cu}-$ Ga system [15] the solubility of the Ga metals in the YCu intermetallic at $700^{\circ} \mathrm{C}$ reaches $20 \%$ at. So, six gallium-containing samples of this solid solution ( 7 in total) are prepared for further study of the kinetics of isothermal oxidation of $\mathrm{YCu}_{1-x} \mathrm{Ga}_{x}$ powder, namely, $0,2.5,5.0,7.5$, $10.0,12.5$, and $15 \%$ at. Ga. Wherein, the XRD study of the initial powder samples revealed that they are single-phase $\mathrm{YCu}_{1-x} \mathrm{Ga}_{x}$ $(0 \leq x \leq 0.3)$ solid solution ones and their lattice parameters vary linearly upon the concentration range of $0-15 \%$ at. Ga (Fig. 1).

These initial powders being preliminary tested by XRD analysis are annealed at three different temperatures in air until their complete oxidation, namely: 4000,2500 , and $1000 \mathrm{~min}$ for 500,600 , and $650^{\circ} \mathrm{C}$, respectively. Fragments of these experimental kinetic curves of isothermal oxidation are shown at Fig. 2. The completion of the oxidation process is judged by the asymptotic achievement of maximum $\alpha(t)$ value as well as by invariability of the phase composition of the tested samples containing oxides only. Character of the change in the phase composition of the oxidation products will be described in detail below.

Previously a poly-staged character of oxidation process for bulk yttrium and copper metals is established as a result of the experiments on their solid-phase oxidation in Refs. [8, 10, 11]. Namely, the first stage of oxidation process is found to be predominantly caused by the grain boundary diffusion of the atoms oxygen and is accompanied by formation of the oxide scale. This oxide scale, growing on a sample surface, gradually decreases the rate of the oxygen atoms diffusion. At a certain thickness of oxide scale the second stage of the oxidation process begins that is described by the quadratic equation and is charac-

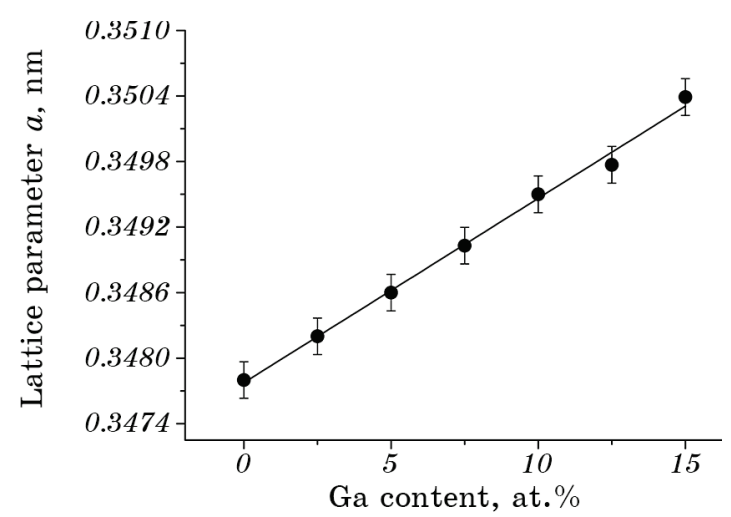

Fig. 1. Concentration dependences of lattice parameters a for the $\mathrm{YCu}_{1-x} \mathrm{Ga}_{x}$ solid solution. 
terized by a changeless diffusion (oxidation) rate.

Considering the complete oxidation in air at 500,600 , and $650^{\circ} \mathrm{C}$ of the $\mathrm{YCu}_{1-x} \mathrm{Ga}_{x}$ powders obtained here (Fig. 2), a mathematical function that would describe the experimental $\alpha(t)$ dependence and match the physical models of the phase transformations theory is chosen [18] The most suitable mathematical function is as follows:

$$
\alpha(T)=A_{0}+A_{1}\left[1-\exp \left(-k_{1} t\right)\right]+A_{2}\left[1-\exp \left(-k_{2} t\right)\right],
$$

where $t$ is the oxidation time, $A_{0}, A_{1}$ and $A_{2}$ are constants, $k_{1}$ and $k_{2}$ are the coefficients listed in Table 1.

In general, Eq. (1) could be rewritten as $\alpha(t)=A_{0}+A_{1} \exp 1+A_{2} \exp 2$. Figure 2 illustrates a fragment of the experimental $\alpha(t)$ curve for $\mathrm{YCu}$ powder oxidized at $600^{\circ} \mathrm{C}$ (circles) fitted by Eq. (1). It is clearly seen that the equation term $A_{2} \exp 2$ becomes dominant and completely reproduces the experimental $\alpha(t)$ curve (the second stage of oxidation) after 30 min of annealing, while at the initial stages of oxidation the prevailing role moves to $A_{1} \exp 1$ term (the first stage of oxidation).
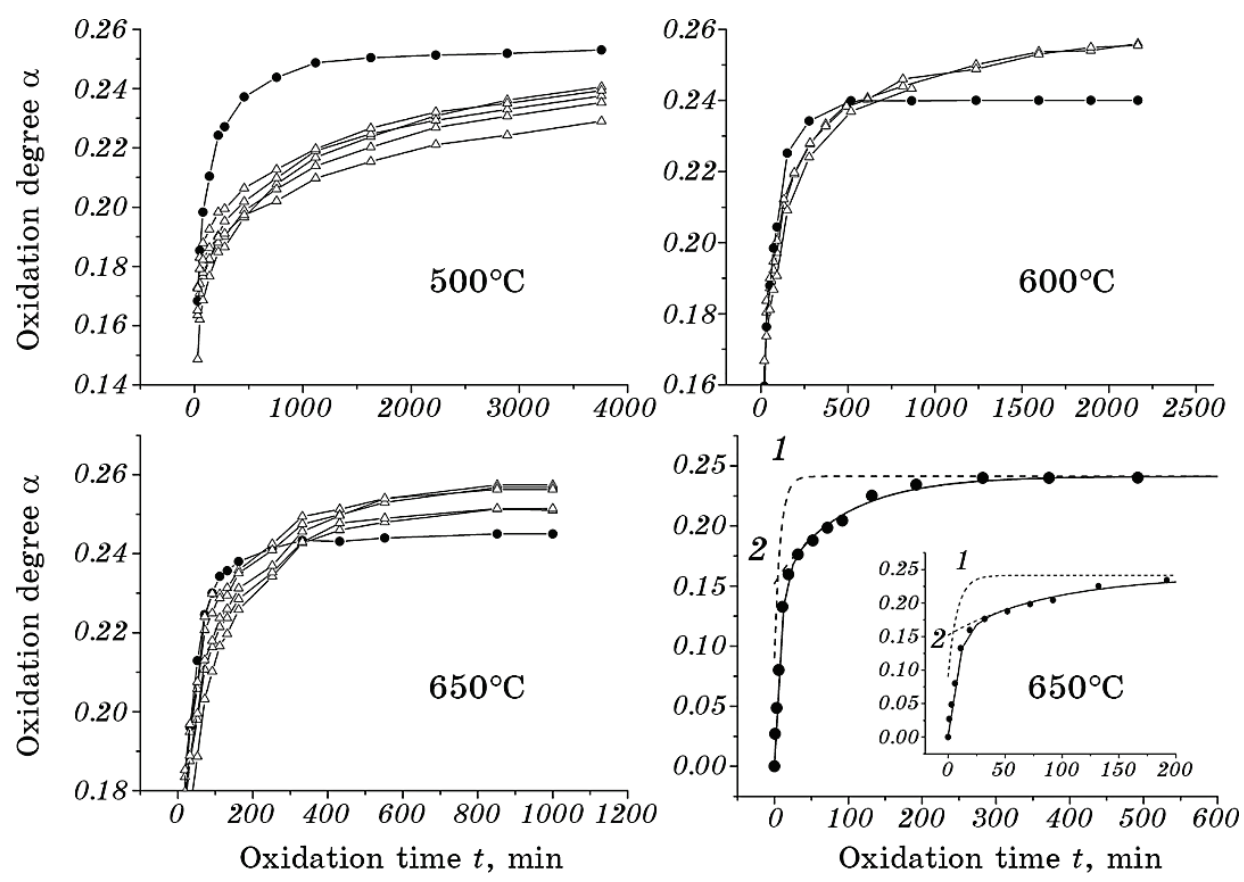

Fig. 2. Three fragments of $\alpha(t)$ dependences for $\mathrm{YCu}_{1-x} \mathrm{Ga}_{x}(0 \leq x \leq 0.3)$ powders (data for YCu sample are marked as black circles, data for gallium containing samples are marked as empty triangles, curves fitted by Eq. (1) are marked as solid lines) and a fragment of processing of the $\alpha(t)$ curve for $\mathrm{YCu}$ $\left(600^{\circ} \mathrm{C}\right)$ by $A_{1} \exp 1$ (1) and $A_{2} \exp 2$ (2) components (dashed lines). 
TABLE 1. Isothermal oxidation rates for the $\mathrm{YCu}_{1-x} \mathrm{Ga}_{x}$ solid solution powders: Exp. are experimentally measured $k_{1}$ and $k_{2}$ parameters, error in determining these values by Eq. (1) does not exceed $10 \%$, Calc. are $k_{2}$ values are calculated by Eq. (4) or by polynomial of the second degree (values in the brackets).

\begin{tabular}{|c|c|c|c|c|c|c|c|c|c|}
\hline \multirow{3}{*}{$\begin{array}{c}\mathrm{Ga} \\
\text { content, } \\
\text { (\% at.) }\end{array}$} & \multicolumn{3}{|c|}{$500^{\circ} \mathrm{C}$} & \multicolumn{3}{|c|}{$600^{\circ} \mathrm{C}$} & \multicolumn{3}{|c|}{$650^{\circ} \mathrm{C}$} \\
\hline & \multirow{2}{*}{\begin{tabular}{|c|}
$\begin{array}{c}k_{1} \cdot 10^{-3} \\
\min ^{-1}\end{array}$ \\
Exp.
\end{tabular}} & \multicolumn{2}{|c|}{$\begin{array}{c}k_{2} \cdot 10^{-5} \\
\min ^{-1}\end{array}$} & \multirow{2}{*}{\begin{tabular}{|c|}
$\begin{array}{c}k_{1} \cdot 10^{-3} \\
\min ^{-1}\end{array}$ \\
$\operatorname{Exp}$.
\end{tabular}} & \multicolumn{2}{|c|}{$\begin{array}{r}k_{2} \cdot 10^{-5} \\
\min ^{-1}\end{array}$} & \multirow{2}{*}{$\begin{array}{c}\begin{array}{c}k_{1} \cdot 10^{-3} \\
\min ^{-1}\end{array} \\
\text { Exp. }\end{array}$} & \multicolumn{2}{|c|}{$\begin{array}{r}k_{2} \cdot 10^{-5} \\
\min ^{-1}\end{array}$} \\
\hline & & Exp. & Calc. & & Exp. & Calc. & & Exp. & Calc. \\
\hline 0 & 22 & 114 & 112 & 50 & 550 & 539 & 67 & 920 & $1041(915)$ \\
\hline 2.5 & 25 & 91 & 98 & 58 & 440 & 426 & 68 & 730 & $786(735)$ \\
\hline 5 & 28 & 83 & 86 & 62 & 321 & 336 & 70 & 587 & $594(596)$ \\
\hline 7.5 & 29 & 81 & 76 & 57 & 251 & 266 & 79 & 489 & $449(498)$ \\
\hline 10 & 29 & 75 & 67 & 58 & 224 & 210 & 83 & 441 & $339(440)$ \\
\hline 12.5 & - & 67 & 59 & - & 222 & 166 & - & 420 & $199(424)$ \\
\hline 15 & - & - & 52 & - & - & 131 & - & 430 & $143(448)$ \\
\hline
\end{tabular}

Moreover, experimental constants $A_{1}$ and $A_{2}$ vary as: $0.03<\left(A_{1}\right.$, $\left.A_{2}\right)<0.05$ at $500^{\circ} \mathrm{C}, 0.14<A_{1}<0.18$ and $0.06<A_{2}<0.08$ at $600^{\circ} \mathrm{C}$, $0.18<A_{1}<0.20$ and $0.04<A_{2}<0.06$ at $650^{\circ} \mathrm{C}$.

It is known that if the oxidation proceeds as

$$
\alpha=N_{0}\left[1-\exp \left(-k_{\mathrm{eff}} t^{n}\right)\right]
$$

where $k_{\text {eff }}$ is the oxidation rate, $N_{0}$ is the number of nucleation centres, then the oxidation behaviour is associated with the active nucleation centres according to a formal theory of transformations kinetics [18]. Replotting the experimental dependences obtained as $(-\ln (1-\alpha(t)))$ vs $\ln (t)$ and analysing them, one could conclude that power $n$ in Eq. (2) is close to $n \approx 0.8-0.9$ for all kinetic curves.

The experimental $k_{1}$ and $k_{2}$ values listed in Table 1 are determined by applying Eq. (1) to each isothermal oxidation kinetic curves studied. The following should be noted: the first, $k_{1}>>k_{2}$ and, the second, $k_{1}$ values are almost changeless with the gallium content (Table 1). It is also shown that the concentration dependences $\left(-\ln \left(k_{2}\right)\right)$ for the $\mathrm{YCu}_{1-x} \mathrm{Ga}_{x}$ powders with up to $7.5 \%$ at. of Ga could be successfully approximated by linear function (Fig. 3) in the temperature range studied $\left(500-650^{\circ} \mathrm{C}\right)$.

According to the Arrhenius law the temperature dependence of oxidation rate could be written as:

$$
k_{\text {eff }}=S \exp \left(-E_{\text {eff }} / R T\right)
$$


where $k_{\text {eff }}$ is the oxidation rate constant, $T$ is the absolute temperature, $S$ is the pre-exponential factor, $E_{\text {eff }}$ is the activation energy for the reaction, $R$ is the universal gas constant.

Moreover, according to the collision theory the constant $S$ is a frequency of collisions and corresponds to the entropy part of the rate constant as $S=k_{0} \exp (\Delta S / R)$, while if $E=\Delta H$ then the component $\exp (-\Delta H / R T)$ corresponds to its enthalpy part.

So, taking into account Eq. (3), both the entropy and enthalpy parts of the $\mathrm{YCu}_{1-x} \mathrm{Ga}_{x}$ solid solution powder oxidation rates are separated and the activation energy values are determined. As a result, it is found that $k_{1}$ and $k_{2}$ values could be described in temperature range $500-650^{\circ} \mathrm{C}$ by following expressions:

$$
k_{2} \cong S_{02} \exp \left[-\frac{E_{02}(1-0.0223 c)}{R T}\right],
$$

where $c$ is Ga content (\% at.), $S_{02}=k_{02} \exp (-3.535 c / R), k_{02}=1.025 \cdot 10^{3}$ $\min ^{-1}, E_{02}=88228 \mathrm{~J} / \mathrm{mol}$.

At the same time,

$$
k_{1} \cong S_{01} \exp \left(-\frac{E_{01}}{R T}\right)
$$

where $S_{01}=41.2 \mathrm{~min}^{-1}, E_{01}=47616 \mathrm{~J} / \mathrm{mol}$.

It should be noted that the calculated $E_{02}$ value $(88.2 \mathrm{~kJ} / \mathrm{mol})$ is close to the enthalpy of formation of the $\mathrm{YCu}$ compound, namely, $\Delta H_{\mathrm{YCu}}=$ $=76 \mathrm{~kJ} / \mathrm{mol}$ [22], while the calculated $E_{01}$ value $(47.6 \mathrm{~kJ} / \mathrm{mol})$ is close to activation energy of oxidation of the bulk yttrium metal, namely, $44 \mathrm{~kJ} / \mathrm{mol}$ [23].

Analysing the received data one could conclude that the $A_{2} \exp 2$ term

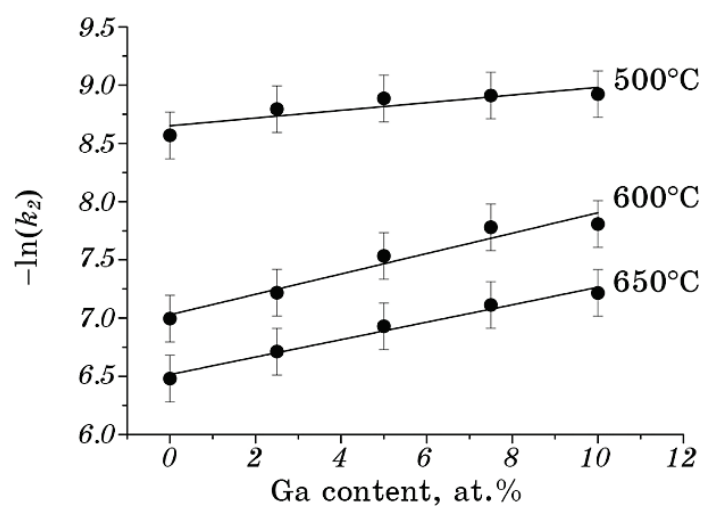

Fig. 3. Concentration dependences of the $\left(-\ln \left(k_{2}\right)\right)$ values of the $\mathrm{YCu}_{1-x} \mathrm{Ga}_{x}$ solid solution powders. 
in Eq. (1) is described by the Eq. (4). This $A_{2} \exp 2$ component dominates at the first stage of the oxidation process (up to $40 \mathrm{~min}$ of annealing in air, Fig. 2) and corresponds to the decomposition of $\mathrm{YCu}$ intermetallic into separate components (see below). So, taking into account experimental $k_{2}$ data (Table 1$)$ the activation energy $\left(E_{02}\right)$ of this process has been calculated (Eq. (4), Fig. 4).

However, the $A_{1} \exp 1$ term in Eq. (1) dominates during the entire oxidation process $\left(A_{1}>A_{2}\right)$ (Fig. 2) and it is well described by the Eq. (5). That is, the oxidation rate $k_{1}$ value is high, slightly depends on temperature at $500-650^{\circ} \mathrm{C}$ range and almost does not depend on the gallium content (Table 1). Obviously, the oxidation rate $k_{1}$ determines the formation of an oxide scale containing $\mathrm{Y}_{2} \mathrm{O}_{3}$ oxide mainly.

So, in our opinion, the $k_{2}$ component of the $\mathrm{YCu}_{1-x} \mathrm{Ga}_{x}$ powder oxidation rate, which is shown to change with the gallium content, is determined by the contribution of the initial solid solution decomposition into its individual components with their subsequent oxidation. These $k_{2}$ values, obtained experimentally and calculated by Eq.(4), are presented in Table 1 and at Fig. 5, which illustrate together a good agreement of these values both at low gallium content and at temperatures up to $650^{\circ} \mathrm{C}$. Although is found that the second-degree polynomial is more suitable for the approximation of the $k_{2}$ experimental data in gallium-rich region of the $\mathrm{YCu}_{1-x} \mathrm{Ga}_{x}$ solid solution (dashed lines in Fig. 5, Table 1).

According to XRD data the phase composition of the powders studied changes significantly throughout the entire oxidation. Thus, the test samples selected at the initial stage (up to $40 \mathrm{~min}$ ) of isothermal annealing of powders contain four phases, namely, the $\mathrm{YCu}_{2}$ intermatallic, the initial $\mathrm{YCu}_{1-x} \mathrm{Ga}_{x}$ solid solution with the unchanged lattice parameter and two other cubic yttrium phases: $\mathrm{Y}_{2} \mathrm{O}_{3}$ oxide with $a=1.060(1) \mathrm{nm}$ and presumptive (Y, Cu)O ${ }_{y}$ phase with $a \approx 5.202(6) \mathrm{nm}$

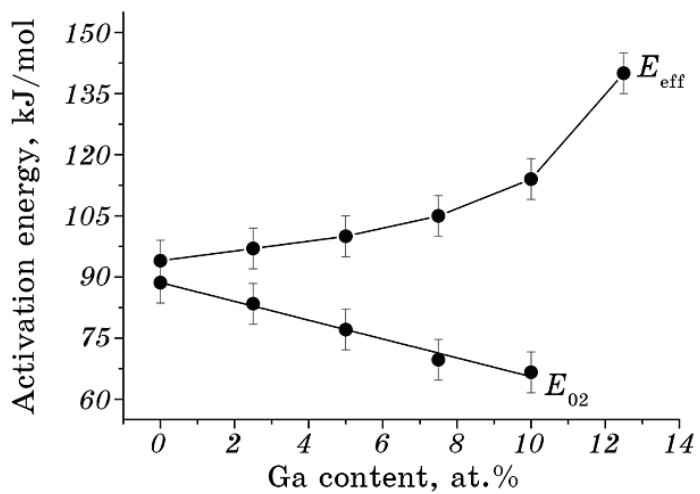

Fig. 4. Concentration dependences of $E_{02}$ activation energy and $E_{\text {eff }}$ apparent activation energy of oxidation of $\mathrm{YCu}_{1-x} \mathrm{Ga}_{x}$ powders. 

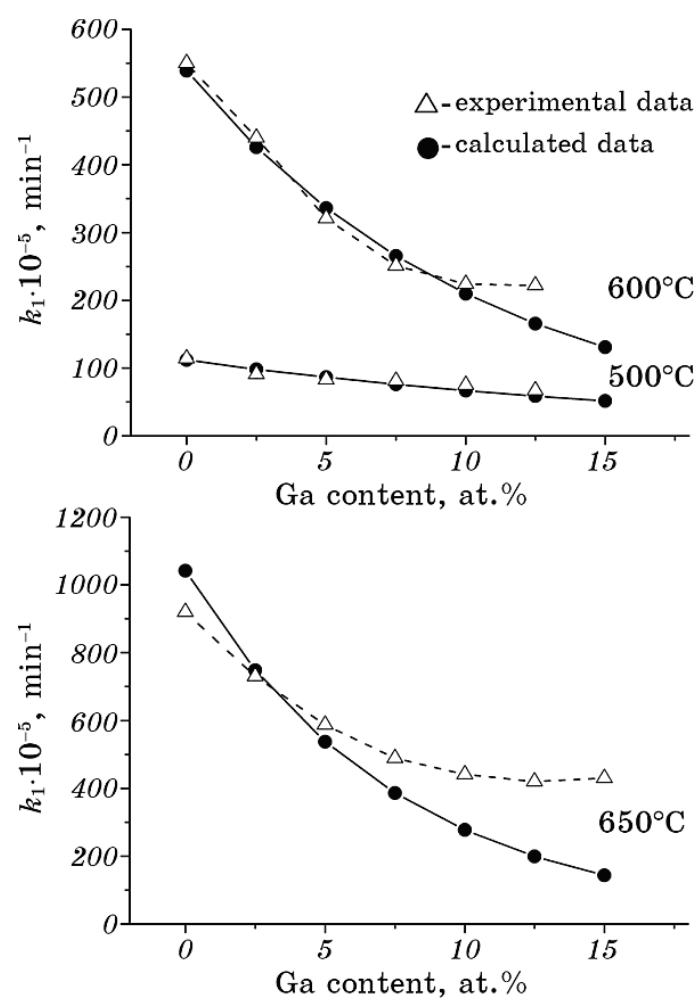

Fig. 5. Concentration dependences of the $k_{2}$ oxidation rate values: experimental and calculated by Eq. (4) (solid line) ones.

(Fig. 6). Recently we are found $[6,24]$ that such $\mathrm{Y}_{1-x} \mathrm{Cu}_{x} \mathrm{O}_{y}$ cubic phases $(a=0.500-0.488 \mathrm{~nm}$ with $0-30 \%$ at. of $\mathrm{Cu})$ are formed at mechanical alloying in air of the $\mathrm{Y}-\mathrm{Cu}$ powder mixture (YCu equiatomic composition). As for ' $\mathrm{YCu} 2$ ' phases formed at oxidation of $\mathrm{YCu}_{1-x} \mathrm{Ga}_{x}$ powders with $x>0$, they really are the $\mathrm{Y}(\mathrm{Cu}, \mathrm{Ga})_{2}$ solid solution phases, whose lattice parameters depend on the gallium content in the sample.

Thus, the first stage of the oxidation of all the solid solution powders studied is accompanied by such transformation (decomposition of initial $\mathrm{YCu}_{1-x} \mathrm{Ga}_{x}$ solid solution) followed by oxidation as (here, the virtual phases that are not detected by XRD method, are marked in brackets):

$$
\begin{aligned}
\mathrm{YCu}_{1-x} \mathrm{Ga}_{x} \rightarrow & \mathrm{Y}(\mathrm{Cu}, \mathrm{Ga})_{2}+[\mathrm{Y}]+[\mathrm{Ga}] \stackrel{\mathrm{O}_{2}}{\longrightarrow} \mathrm{Y}(\mathrm{Cu}, \mathrm{Ga})_{2}+ \\
& +\mathrm{Y}_{2} \mathrm{O}_{3}+(\mathrm{Y}, \mathrm{Cu}) \mathrm{O}_{y}+\left[\mathrm{Ga}_{2} \mathrm{O}_{3}\right] .
\end{aligned}
$$

In our opinion, an oxide scale and its further transformation is formed at this stage of oxidation. Because of these transformations, the 
final oxidation products contain yttrium and copper oxides only, namely, $\mathrm{Y}_{2} \mathrm{O}_{3}, \mathrm{CuO}$, and $\mathrm{Cu}_{2} \mathrm{O}$ (Fig. 6) according to the XRD data. Moreover, the lattice parameters of these oxides strictly correspond to their known values.

As for $\mathrm{Ga}_{2} \mathrm{O}_{3}$, it is known [25] that the deposited thin films of this oxide are amorphous and $\mathrm{Ga}_{2} \mathrm{O}_{3}$ phase is not detected by XRD. So, although in this study $\mathrm{Ga}_{2} \mathrm{O}_{3}$ oxide is not detected by XRD method, it certainly participates in the oxide scale formation. Thus, complete oxidation of $\mathrm{YCu}_{1-x} \mathrm{Ga}_{x}$ solid solution powders is carried out as follows:

$$
\mathrm{YCu}_{1-x} \mathrm{Ga}_{x} \rightarrow \stackrel{\mathrm{O}_{2}}{\longrightarrow} \mathrm{Y}_{2} \mathrm{O}_{3}+\mathrm{CuO}+\left[\mathrm{Ga}_{2} \mathrm{O}_{3}\right] .
$$

Study of isothermal annealing of the $\mathrm{YCu}_{1-x} \mathrm{Ga}_{x}$ powders in air has discovered the main features of their complete oxidation. The process of complete oxidation is preceded by the decomposition of initial material with the formation of metastable intermediate phases such as $\mathrm{YCu}_{2}$ and $(\mathrm{Y}, \mathrm{Cu}) \mathrm{O}_{y}$. This conclusion is proved by the XRD results and by a proximity of the oxidation activation energy for the powders with $x=0$ $(88.2 \mathrm{~kJ} / \mathrm{mol}$, Fig. 4) and the formation enthalpy of pure $\mathrm{YCu}$ compound $(76 \mathrm{~kJ} / \mathrm{mol}[22])$.

Since the decomposition of the binary $\mathrm{YCu}(x=0)$ compound proceeds according to the scheme (6) too, then results obtained in this work are compared with oxidation behaviour of bulk yttrium metal. It should be noted that the activation energy of oxidation in air of this metal, which is equal to $44 \mathrm{~kJ} / \mathrm{mol}[10]$, is close to $E_{01}=48 \mathrm{~kJ} / \mathrm{mol}$, which we obtained for the first stage of the $\mathrm{YCu}$ oxidation process from Eq. (5). That is, the oxidation of the decomposition products of the $\mathrm{YCu}$ compound starts with the oxidation of yttrium atoms with the
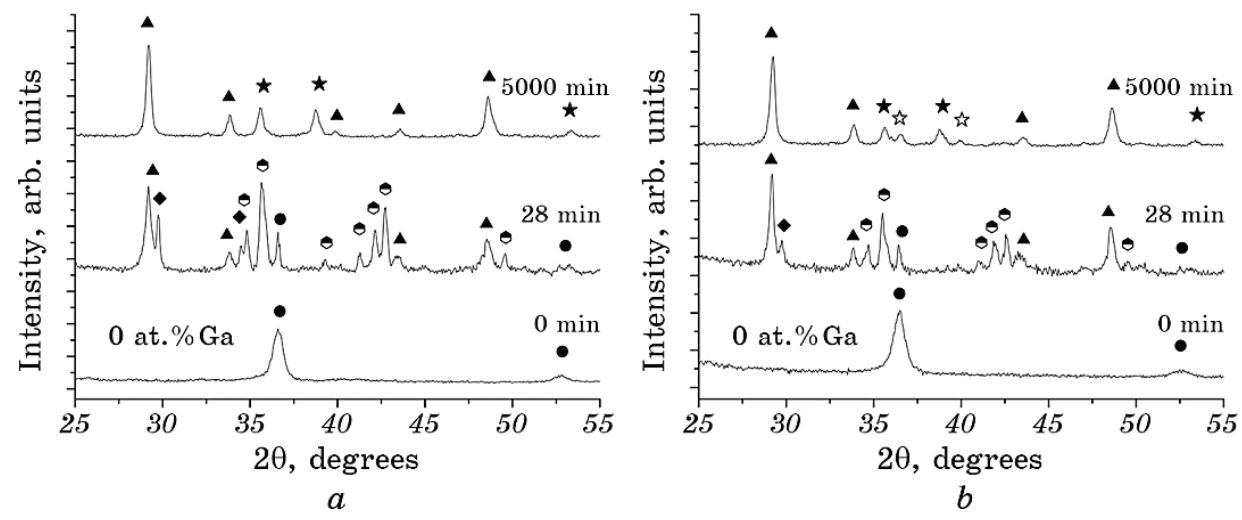

Fig. 6. Fragments of diffraction patterns for $\mathrm{YCu}_{1-x} \mathrm{Ga}_{x}$ powders selected after different oxidation times at $500^{\circ} \mathrm{C}$. Markers for individual phases are shown in Fig. 7. 
formation of $\mathrm{Y}_{2} \mathrm{O}_{3}$ oxide scale. Further oxidation of $\mathrm{YCu}$ intermetallic is retarded with growth of this scale, which thickness could reach $100 \mu \mathrm{m}$ in bulk yttrium $[10,11]$. Thus, our results obtained for the oxidation of $\mathrm{YCu}$ powders in air coincide with those obtained for the bulk yttrium material.

It is clear that oxidation of the $\mathrm{YCu}_{1-x} \mathrm{Ga}_{x}$ solid solution powders $(x>0)$ is accompanied by a change in the phase composition of the oxide scale. Since any gallium oxides and phases $\left(\mathrm{Ga}_{2} \mathrm{O}_{3}, \mathrm{CuGa}_{2} \mathrm{O}_{4}\right.$, etc.) are not detected in the oxidation products by the XRD method the effect of Ga dopants on the oxidation is studied by analysing $k_{\text {eff }}$ parameter obtained by approximating the experimental curves (Fig. 2) by singleterm equation as follows:

$$
\alpha(T)=A_{0}+A_{\text {eff }}\left[1-\exp \left(-k_{\text {eff }} t\right)\right],
$$

Despite the large error in determining $k_{\text {eff }}$ value by a single-term Eq.
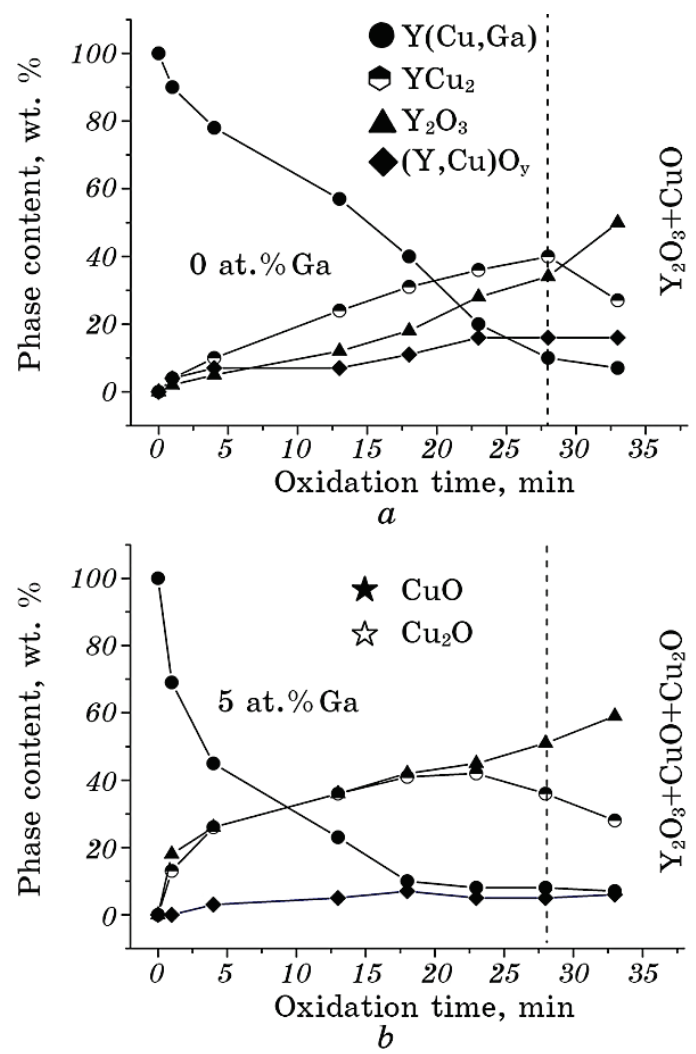

Fig. 7. Phase fractions (\% wt.) of the $\mathrm{YCu}_{1-x} \mathrm{Ga}_{x}$ powders annealed at $500^{\circ} \mathrm{C}$ versus oxidation time up to $40 \mathrm{~min}$. 
(7), it is found that the apparent activation energy $E_{\text {eff }}$ increases significantly with an increase of Ga content in the $\mathrm{YCu}_{1-x} \mathrm{Ga}_{x}$ powder (Fig. 7).

Here we have shown that $\alpha(t)$ dependences for the $\mathrm{YCu}_{1-x} \mathrm{Ga}_{x}$ powders are correctly described by a two-term Eq. (1). Moreover, the first term of the $\alpha(t)$ expression for $\mathrm{YCu}_{1-x} \mathrm{Ga}_{x}$ probably corresponds to the formation of $\mathrm{Y}_{2} \mathrm{O}_{3}$ oxide scale at the initial stage of the oxidation process. Upon further annealing this oxide scale supplemented by both copper and gallium oxides and as a result it significantly retards the diffusion of atmospheric oxygen atoms along the grain boundaries and the oxidation.

On the whole, the oxidation reactions of the $\mathrm{YCu}_{1-x} \mathrm{Ga}_{x}$ solid solution powders occur at the rates that decrease with gallium content increasing (Fig. 5, Table 1), which means that the oxidation resistance of these powders increases.

\section{CONCLUSIONS}

The kinetics of isothermal $\left(500,600\right.$, and $\left.650^{\circ} \mathrm{C}\right)$ oxidation in air of the powders (of $50 \mu \mathrm{m}$ of size) of the $\mathrm{YCu}_{1-x} \mathrm{Ga}_{x}(0 \leq x<0.3$ ) solid solution on the base of $\mathrm{YCu}$ compound has been studied by the periodic weighment method and XRD phase analysis. This study has revealed some features of the oxidation mechanisms of this intermetallic compound.

It is shown that oxidation of the $\mathrm{YCu}_{1-x} \mathrm{Ga}_{x}$ powders follows the scheme:

$$
\begin{gathered}
\mathrm{YCu}_{1-x} \mathrm{Ga}_{x} \stackrel{\mathrm{O}_{2}}{\longrightarrow} \mathrm{Y}(\mathrm{Cu}, \mathrm{Ga})_{2}+\mathrm{Y}_{2} \mathrm{O}_{3}+(\mathrm{Y}, \mathrm{Cu}) \mathrm{O}_{y}+ \\
+\left[\mathrm{Ga}_{2} \mathrm{O}_{3}\right] \stackrel{\mathrm{O}_{2}}{\longrightarrow} \mathrm{Y}_{2} \mathrm{O}_{3}+\mathrm{CuO}+\left[\mathrm{Ga}_{2} \mathrm{O}_{3}\right] .
\end{gathered}
$$

The oxidation process of $\mathrm{YCu}_{1-x} \mathrm{Ga}_{x}$ powders occurs in two stages. The initial stage of oxidation (with activation energy of $48 \mathrm{~kJ} / \mathrm{mol}$ ) is characterized by the formation of a stable oxide scale, containing $\mathrm{Y}_{2} \mathrm{O}_{3}$ mainly. Upon further annealing this scale formed significantly retards both the diffusion of oxygen atoms along the grain boundaries and the oxidation process since this oxide scale is completed by both copper and gallium oxides at phase transformations. In whole, the oxidation rate of the $\mathrm{YCu}_{1-x} \mathrm{Ga}_{x}$ solid solution decreases with an increase in the gallium content, while the apparent activation energy of oxidation increases.

Overall, gallium dopants increase the resistance to high-temperature oxidation of the $\mathrm{YCu}$ phase under its annealing at $500-650^{\circ} \mathrm{C}$ in air.

\section{REFERENCES}

1. K. Gschneidner, A. Russell, A. Pecharsky, J. Morris, Z. Zhang, T. Lograsso, D. Hsu, C. H. Chester Lo, Y. Ye, A. Slager, and D. Kesse, Nat. Mater., 2: 587 
(2003).

2. A. M. Russell, Z. Zhang, K. A. Gschneidner Jr., T. A. Lograsso,

A. O. Pecharsky, A. J. Slager, and D. C. Kesse, Intermetallics, 13: 565 (2005).

3. S. H. Williams, In-Situ Neutron Diffraction Analysis of Deformation Behaviour of Ductile Rare-Earth Intermetallic YCu (Disser. for PhD) (Iowa: Iowa State University: 2009).

4. A. T. Becker, The Yield Strength and Flow Stress Anomaly in B2 Yttrium Copper (Disser. for PhD) (Iowa: Iowa State University: 2010).

5. Z. Zhang, A. M. Russell, S. B. Biner, K. A. Gschneidner, and C. C. H. Lo, Intermetallics, 13, No. 5: 559 (2005).

6. M. Dashevskyi, O. Boshko, O. Nakonechna, and N. Belyavina, Metallofiz. Noveishie Tekhnol., 39, No. 4: 541 (2017).

7. M. Dashevskyi, N. Belyavina, O. Boshko, L. Kapitanchuk, O. Nakonechna, and S. Revo, Adv. Powder Technol., 29, No. 5: 1106 (2018).

8. Y. Zhu, K. Mimura, J.-W. Lim, M. Isshiki, and Q. Jiang, Metallurgical Materials Transactions A, 37: 1231 (2006).

9. D. Serafin, W. J. Nowak, and B. Wierzba, Applied Surface Science, 476: 442 (2019).

10. H. J. Borchardt, J. Inorganic and Nuclear Chemistry, 26, No. 5: 771 (1964).

11. O. N. Carlson, F. A. Schmidt, and R. L. Wells, A Study of the High-Temperature Air Oxidation of Yttrium Metal.Ames Laboratory Technical Reports (Iowa: Iowa State University: 1960).

12. K. J. Qiu, W. J. Lin, F. Y. Zhou, H. Q. Nan, B. L. Wang, L. Li, J. P. Lin, Y. F. Zheng, and Y. H. Liu, Mater. Sci.Eng. C, 34: 474 (2014).

13. H. F. Li, K. J. Qiu, W. Yuan, F. Y. Zhou, B. L. Wang, L. Li, Y. F. Zheng, and Y. H. Liu, Scientific Reports, 6: 37428 (2016).

14. X. Liu, S. Chen, J. K. Tsoi, and J. P. Matinlinna, Regenerative Biomaterials, 4, No. 5: 315 (2017).

15. N. Belyavina, V. Markiv, and O. Nakonechna, J.Alloys and Compounds, 541: 288 (2012).

16. N. N. Belyavina, V. Ya. Markiv, M. V. Mathieu, and O. I. Nakonechna, J.Alloys and Compounds, 523: 114 (2012).

17. V. K. Pecharsky and P. Y. Zavalij, Fundamentals of Powder Diffraction and Structural Characterization of Materials (New York: Springer: 2009).

18. J. W. Christian, The Theory of Transformations in Metals and Alloys, ch. 1: 1 (2002).

19. L. Kaufman and B. Ditchek, J.Less-Common Metals, 168, Iss. 1:115 (1991).

20. F. Saidi, M. K. Benabadji, H. I. Faraoun, and H. Aourag, Computational Materials Science, 89: 176 (2014).

21. T. Takahashi, T. Yamane, Y. Minamino, and T. Kimura, J. Material Science Letters, 8: 882 (1989).

22. A. R. Miedema, J. Less-Common Metals, 46, Iss. 1: 67 (1976).

23. O. Nakonechna, M. Dashevskyi, A. Kurylyuk, N. Belyavina, and V. Makara, Metallofiz. Noveishie Tekhnol., 42, No. 5: 695 (2020).

24. I. A. Hassan, S. Sathasivam, H. U. Islam, S. P. Nair, and C. J. Carmalt, RSC Advances, 7, No. 1: 551 (2017). 